\title{
Etika Aparatur Sipil Negara dalam Membangun Good Governance
}

\author{
Tulus Santoso ${ }^{1, *}$, Maya Puspita Dewi ${ }^{2}$ \\ ${ }^{1}$ Institut Ilmu Sosial dan Manajemen STIAMI, Jakarta Pusat, 10530, Indonesia \\ 2 Institut Ilmu Sosial dan Manajemen STIAMI, Jakarta Pusat, 10530. Indonesia \\ ${ }^{1}$ tulus@stiami.ac.id*; ${ }^{2}$ maya.pd@stiami.ac.id \\ * corresponding author
}

\section{ARTICLE INFO}

\section{Article history}

Received 2019-11-18

Revised 2019-12-02

Accepted 2019-12-09

\section{Keywords \\ Ethic \\ Civil Servants Ethics \\ Good Governance}

\begin{abstract}
Civil servants as a government apparatus are required to have ethics. However, the phenomenon of many civil servants being convicted of corruption and still receiving salaries, even filed a lawsuit, left a big question mark regarding their compliance with ethics. The method used in this paper is a literature study. The results showed that corruption is a violation of ethics and the reluctance to resign and even sue when dismissal is clearly contrary to ethical behavior. Legal norms as a manifestation of ethics in the form of written law and an embodiment of good governance are good enough, it's just that law enforcement must be done by superiors, Staff Development Officers are not done and they become part of those who also violate ethics because they do not want to uphold ethics in his environment. This also is not in line with the spirit of good governance that not only wants the rule of law but also must have law enforcement. In the future, as an effort to create ethical Civil Servants, law enforcement must be carried out absolutely.
\end{abstract}

\section{PENDAHULUAN}

Sebagai ujung tombak pelayanan publik, Aparatur Sipil Negara (ASN) selalu menjadi sorotan masyarakat. Hal ini sebenarnya wajar, karena memang masyarakat merupakan pihak yang selalu bersentuhan dengan aparatur pemerintah. Hubungan mereka adalah sebagai penerima dan pemberi layanan. Ekspektasi dari publik adalah bahwa ASN harus mampu memberikan pelayanan yang profesional kepada masyarakat. Publik menginginkan para birokrat taat dan patuh pada aturan yang berlaku dan menjaga integritasnya. Sehingga, setiap ada tindakan dari ASN yang menyimpang, pasti akan mendapatkan reaksi dari publik.

Posisi birokrasi dan aparaturnya dalam relasi pemerintah dengan rakyat memegang peranan yang sangat penting. Sebagaimana dikatakan Hegel dalam Noer (2014), birokrasi merupakan jembatan antara negara dengan rakyatnya. Namun sayangnya, aparatur birokrasi semakin gagal mempertahankan kinerjanya sebagai alat pelaksana kebijakan negara (Iskandar, 2016). Persoalan kedisiplinan, KKN (korupsi, kolusi, dan nepotisme), dan kualitas sumber daya manusia (SDM) seakan menjadi penyakit (patologi) menahun yang tak kunjung terobati. Birokrasi yang sakit pun harus kita hadapi sebagai kenyataan di republik ini.

Menurut Siagian (1999) sebagaimana dikutip oleh Hamirul (2017), patologi birokrasi dapat dikelompokkan menjadi 5, yaitu: Patologi birokrasi yang muncul karena adanya persepsi dan gaya manajerial dari pejabat di lingkungan birokrasi; Patologi yang lahir karena rendahnya pengetahuan dan keterampilan petugas pelaksana di level operasional; Patologi yang timbul karena tindakan aparat birokrasi yang melanggar aturan hukum dan perundang-undangan yang berlaku; Patologi yang berwujud dalam tindakan birokrat yang disfungsional atau negatif; Terakhir adalah patologi yang timbul sebagai akibat dari situasi internal di berbagai instansi pemerintahan.

Lebih lanjut, bicara birokrasi dan aparaturnya, sebagaimana dikatakan oleh Nigro \& Nigro (2012: 440) memang lekat dengan mal administrasi yang tercermin dalam tindakan dan perilaku sebagai berikut:

1. Tidak jujur, yaitu suatu tindakan administrasi yang tidak jujur, misalnya para pegawai negeri mencuri dari pemerintah. Melaporkan pemasukan secara keliru, menerima suap, pungli;

2. Berperilaku tidak etis. Mereka mungkin tidak menerima suap tapi keputusan yang dibuat menguntungkan keluarganya atau koleganya (nepotisme). 
3. Tidak menghormati hukum, pegawai mungkin sengaja mengabaikan hukum atau mengintepretasikannya sedemikian rupa untuk membenarkan tindakan yang ingin diambilnya.

4. Tebang pilih dalam menafsirkan hukum, maksudnya adalah pegawai di suatu instansi tetap mengikuti hukum yang berlaku, tetapi hukum tersebut ditafsirkan atau dicarikan peluangnya untuk menguntungkan kepentingan tertentu.

5. Perlakuan yang tidak adil kepada pegawai. Lembaga kadang memperlakukan pegawai dan stafnya dengan tidak adil, bahkan menghukum mereka dengan sanksi pemecatan bila jujur dan mengatakan yang sebenarnya.

6. Tidak efisien dan tidak efektif, Pemborosan dana secara berlebihan. Pejabat yang tidak menyukai efisiensi adalah pejabat yang tidak bertanggungjawab, tak peduli seberapa jujur dirinya;

7. Menutup-nutupi kesalahan. Terlihat heroik tapi sejatinya menutupi kesalahan.

8. Gagal memperlihatkan inisiatif. Gagal membuat keputusan yang positif dan mengembangkan potensi yang mereka miliki dengan benar sesuai hukum.

Harapan akan hadirnya birokrasi yang beretika, memiliki integritas, dan bebas dari KKN menjadi kebutuhan mendesak yang harus segera diwujudkan. Tapi upaya untuk merealisasikannya tidak mudah. Serangkaian pelanggaran disiplin, penyalahgunaan kewenangan, belum diimplementasikannya peraturan perundangan secara konsisten, sistem pengendalian yang belum efektif, dan rendahnya kualitas SDM aparatur pemerintah menjadi tantangan tersendiri (Sedarmayanti \& Nurliawati, 2012).

Sebagai contoh mengenai tercorengnya etika aparatur pemerintah adalah ketika di penghujung tahun 2018, Badan Kepegawaian Negara (BKN) menyampaikan ada ribuan Aparatur Sipil Negara (ASN) yang terlibat tindak pidana korupsi (Tipikor) dan sudah berkekuatan hukum tetap (BHT) tapi masih menerima gaji dari negara. Hal ini terjadi lantaran Pejabat Pembina Kepegawaian (PPK) belum melakukan pemberhentian tidak dengan hormat (PTDH) terhadap mereka yang sudah divonis bersalah (BKN, 2018).

Upaya untuk menindaklanjuti ASN bermasalah ini berjalan sangat lambat. Dari total 2.357 ASN yang terlibat tipikor dan keputusannya sudah inkracht, hingga Agustus 2019 baru terselesaikan sebanyak 1.966 atau masih kurang 391 orang lagi. Padahal, pemerintah sudah mengeluarkan Surat Keputusan Bersama (SKB) antara BKN, Kemenpan RB, dan Kemendagri Nomor: 182/6597/SJ, Nomor: 15 Tahun 2018, dan Nomor:153/KEP/2018 Tentang Penegakan Hukum terhadap Pegawai Negeri Sipil yang Telah Dijatuhi Hukuman Berdasarkan Putusan Pengadilan yang Berkekuatan Hukum Tetap Karena MelakukanTindak Pidana Kejahatan Jabatan atau Tindak Pidana yang Ada Hubungannya dengan Jabatan.

Menurut BKN, lambatnya upaya melakukan PTDH disebabkan oleh beberapa faktor, antara lain instansi yang masih menunggu terbitnya putusan MK terkait gugatan Pasal 87 ayat (4) huruf b dalam UU 5/2014 tentang ASN yang dijadikan dalih penundaan untuk melakukan PTDH; Adanya mutasi ASN Tipikor BHT sebelum dilakukan pemberhentian oleh instansi asal, sehingga namanya tidak masuk daftar pemblokiran data kepegawaian BKN. Selain itu, ada juga ASN Tipikor BHT yang sudah meninggal dunia sebelum dilakukan pemecatan. Alasan terakhir ternyata sejumlah PPK memang belum melakukan proses PTDH.

Terkait dengan statusnya sebagai administratur publik, ASN dituntut untuk memegang teguh etika. Hal ini diperlukan agar masyarakat mendapatkan pelayanan yang berkualitas. Karena dengan adanya etika yang menjadi dasar bertindak bagi ASN diharapkan tidak ada diskriminasi dalam pemberian pelayanan, korupsi dapat dihindari, dan pelayanan publik bisa berjalan dengan efektif dan efisien (Dewi, 2017).

Dalam kaitannya dengan hal tersebut, maka dibuatlah Peraturan Pemerintah No. 42 tahun 2004 tentang Pembinaan Jiwa Korps dan Kode Etik Pegawai Negeri Sipil. Selain itu, ada juga Peraturan Pemerintah No.53 tahun 2010 tentang Disiplin pegawai Negeri Sipil. Aturan mengenai PNS ini kemudian dikuatkan dengan lahirnya UU No.5 tahun 2014 tentang Apartur Sipil Negara.

Sayangnya, peraturan perundangan yang harusnya dapat menjadi pedoman bagi ASN dalam memberikan pelayanan kepada publik tersebut tidak dipatuhi. Berbagai bentuk pelanggaran terjadi, khususnya korupsi. PNS yang telah mendapatkan putusan inkracht dari pengadilan nyatanya tidak diberhentikan. Mereka tidak pula mengundurkan diri dan bahkan melawan dengan mengajukan gugatan terhadap Pasal 87 ayat (4) UU ASN ke Mahkamah Konstitusi. Kondisi ini tentunya sangat jauh dari cita-cita untuk menciptakan SDM ASN yang berintegritas dan profesional dalam upaya memberikan pelayanan kepada publik. Fenomena ASN yang menjadi terpidana korupsi dan menolak mundur, bahkan melakukan "perlawanan" akan menjadi preseden buruk bagi tata kelola ASN di Indonesia.

Beberapa penelitian mencoba mengangkat tema yang sama dengan penulis, diantaranya yaitu tulisan Abas (2017) yang berjudul "Urgensi Etika dalam Tata kelola Pemerintahan (Governance)" mencoba 
mengangkat mengenai tata kelola pemerintahan di Indonesia dan peranan Komisi Aparatur Sipil Negara dalam menegakkan etika ASN. Metode yang dipakai dalam penelitian tersebut sama dengan metode penulis yakni studi pustaka.

Hasil dari penelitian Abas menunjukkan bahwa dalam penyelenggaraan pemerintahan di Indonesia masih terdapat pelanggaran etika yang berbentuk seperti: Degradasi moral penyelenggara negara; Kebohongan publik; Konflik kepentingan; Intervensi proses peradilan; Pembuatan Kebijakan yang tidak efisien; Pengangkatan pejabat yang tidak kompeten; Kurang responsif; Diskrimantif; Kurangnya kepedulian terhadap lingkungan. KASN sendiri telah melakukan penanganan kasus-kasus yang dilaporkan kepada mereka, namun diyakini masih banyak kasus yang tidak dilaporkan kepada KASN.

Selanjutnya, Marsuki (2019) dalam tulisannya yang berjudul "Etika Jabatan dan Aparatur Sipil Negara dalam Prinsip-Prinsip Good Governance" mengupas bagaimana etika sejalan dengan paradigma good governance. Metode yang dipakai dalam penelitian tersebut adalah studi pustaka. Hasilnya menunjukkan bahwa etika kerja ASN selalu berorientasi pada kepentingan rakyat. Sehingga transparansi, keterbukaan, dan akuntabilitas menjadi nilai yang harus dijunjung tinggi dalam etika pergaulan antara pemerintah dengan rakyatnya.

Apa yang disampaikan dalam kedua tulisan di atas memiliki kesamaan dengan apa yang dikaji oleh penulis yakni dalam aspek metodologi. Karena tulisan ini juga menggunakan studi kepustakaan untuk mendapatkan data dan informasi dalam penelitian. Tema besar yang penulis angkat juga sama dengan penelitian sebelumnya, yakni mengenai etika dan kaitannya dengan good governance. Meskipun begitu, titik penekanan yang penulis sampaikan yakni menyangkut fenomena banyaknya ASN yang tersangkut korupsi dan dipidana namun masih berstatus aktif dan menerima gaji dari negara. Ada beberapa hal yang menjadi fokus, yakni dari aspek etika pribadi ASN terkait dengan korupsinya, kemudian terkait juga keengganan untuk tidak mengundurkan diri dan bahkan melawan denga mengajukan gugatan ke MK, terakhir adalah aspek kepemimpinan dari atasan di mana tidak melakukan penegakan disiplin dengan memberhentikan ASN yang bersangkutan.

Penelitian ini akan membahas mengenai aspek etika dalam kasus tersebut, khususnya mengenai minimnya komitmen ASN terhadap peraturan perundangan yang ada dan kaitannya dengan semangat untuk mewujudkan tata kelola pemerintahan yang baik (good governance). Etika yang didalamnya terdapat nilai moral yang diamini oleh individu dan sudah dimanifestasikan menjadi etika organisasi dan jabatan dalam bentuk peraturan perundangan tapi ternyata tidak berjalan sebagaimana mestinya.

Tulisan ini bertujuan ingin memberikan gambaran kepada publik dan pemerintah bahwa ada persoalan dalam etika ASN dimana itu terkait dengan cita-cita atau semangat mewujudkan good governance. Sehingga tulisan ini bukan hanya mampu menambah khasanah kajian mengenai etika administrasi publik tapi juga dapat dijadikan bahan pertimbangan dalam mewujudkan ASN yang beretika.

\section{LANDASAN TEORI}

\section{Etika}

Etika merupakan istilah yang sangat umum kita temui dalam kehidupan sehari-hari. Kita sering menyebut dan menilai tindakan orang lain sebagai perbuatan yang etis dan tidak etis. Secara sederhana, etika dapat diartikan sebagai standar mengenai benar dan salah, baik dan buruk, dan sesuai kaidah moral atau tidak (Kyohairwe, 2015).

Menurut Bertens (2001) sebagaimana dikutip oleh Ibrahim \& Udin (2016) ada tiga arti dalam memahami etika. Pertama, etika diartikan sebagai nilai dan norma moral yang menjadi pegangan bagi seseorang atau kelompok dalam mengatur tingkah lakunya. Kedua, etika sebagai kumpulan asas (nilai moral), kode etik. Ketiga, etika merujuk pada bidang ilmu, yaitu pengkajian secara reflektif mengenai nilainilai moral yang ada dalam masyarakat dengan penelitian yang sitematis dan metodis. Sehingga, dalam kaitannya dengan pengertian ini, etika dikekategorikan sebagai cabang filsafat yang menjadikan moralitas sebagai kajiannya (filsafat moral).

Radhika (2012) dalam Singo (2018) mengatakan bahwa etika dalam administrasi publik merujuk pada standar, norma, peraturan hukum dan nilai sosial yang memandu dan mengatur perilaku pejabat publik. Menentukan standar perilaku yang benar dan salah pada prinsipnya bukanlah perkara mudah. Rasheed (1995) dalam Misra (2016) menyampaikan bahwa etikai tidak bersifat universal, sangat bervariasi tergantung orangnya, tempat, dan waktu.

Lebih lanjut, Darmastuti (2007) dalam Sukri, Idris \& Burhanuddin (2017: 115) mengatakan etika sebagai kajian filsafat dibagi menjadi dua bagian, yaitu: Pertama adalah etika umum, yakni prinsip moral yang mengacu pada moral dasar sebagai pedoman dalam bertindak dan menjadi tolak ukur untuk menilai 
baik buruknya suatu tindakan yang ada didalam suatu masyarakat. Kedua, etika khusus, yakni penerapan moral dasar dalam bidang khusus, misalnya keputusan seseorang untuk bertindak etis dalam bidang tertentu, seperti dalam organisasi, perusahaan, dan sebagainya.

Mengutip pernyataan Kumorotomo (2013) dalam Setiawan (2016: 48) menyebutkan ada ide atau gagasan-gagasan penting yang ada dalam etika administrasi, yaitu:

1. Ketertiban, maksudnya adalah terlaksananya ketentuan-ketentuan, peraturan-peraturan, perintahperintah guna menjamin tetap tegaknya/tetap berlakunya ketentuan dan peraturan tersebut.

2. Efisiensi, merupakan perbandingan yang terbaik antara input dan output (hasil antara keuntungan dengan sumber-sumber yang dipergunakan), seperti halnya juga hasil optimal yang dicapai dengan penggunaan sumber daya yang terbatas.

3. Produktifitas, adalah suatu kinerja yang menunjukan adanya kesimbangan dan keselarasan antara daya guna dengan hasil guna. Produktifitas dapat dikatakan sebagai ukuran pendayagunaan faktor produksi dan tenaga kerja dalam proses produksi

4. Kesadaran moral, yaitu adanya rasa wajib yang tidak bisa ditawar

Marwiyah (2016:7 3-74) menyebutkan ada dua proses yang menyebabkan munculnya etika sebagai sebuah pedoman dalam bertingkah laku. Pertama adalah bahwa etika secara ilmiah terbentuk dari dalam diri manusia (internal) sebagai wujud pemahaman dan keyakinan terhadap suatu nilai tertentu (seperti agama). Kedua, etika diciptakan oleh peraturan-peraturan eksternal yang telah disepakati bersama, seperti janji atau sumpah jabatan, disiplin pegawai, dan sebagainya. Selanjutnya, dalam konteks bagaimana orang bisa antri dengan tertib dan membuang sampah pada tempatnya (disiplin) sebagaimana dipraktikan di Singapura terjadi karena denda yang sangat besar bagi para pelanggarnya.

Etika menjadi sebuah keharusan karena memang kehadirannya sangat penting, sebagaimana disebutkan oleh Ikeanyibe (2009) dalam Abas (2017: 83):

1. Etika sebagai ilmu tindakan manusia melengkapi norma yang mengatur hubungan antar orang. Apa dan bagaimana hubungan tersebut dan mengapa menjadi begitu.

2. Etika sebagai ilmu terapan merupakan dasar bagi bidang-bidang studi dan praktik, hal ini menjadi penting karena berisikan pedoman yang menjadi kode etika dan membimbing tindakan manusia.

3. Etika menegaskan keunikan manusia dibandingkan makhluk lainnya. Hal ini didasarkan pada fakta bahwa kehidupan manusia merupakan konstruksi etis.

4. Dalam tahapan selanjutnya, studi mengenai etika memfasilitasi pembentukan sikap yang mendasar bagi kehidupan yang lebih baik. Pelatihan dalam etika harus memungkinkan kita dapat melihat kecacatan dalam tingkah laku personal dan orang lain, sekaligus untuk memahami sifat yang tepat untuk itu. Sehingga, kita lebih mampu menjalankan sesuatu yang benar dalam perilaku kita dan mampu memberikan saran yang tidak hanya menguntungkan diri sendiri tapi juga orang lain.

5. Etika berfungsi sebagai strategi sosial untuk meningkatkan kehidupan manusia melalui pelestarian ekosistem yang lebih manusiawi dan untuk mencapai harmoni sosial dan global. Hal ini berarti memfasilitasi nilai-nilai sosial umum, penghargaan/memperkuat nilai-nilai positif.

6. Etika hakikatnya telah terjalin dengan agama. Kebanyakan agama yang dibangun di atas prinsip dasar bahwa perilaku yang baik akan dihargai dan perilaku yang buruk akan mendapatkan hukuman. Relasi etika dengan agama memberikan alasan utama untuk melakukan perbuatan yang benar dan menghindari kejahatan. Hal Ini tentunya sejalan dengan naluri manusia pada umumnya dalam beragama.

Menurut Nurdin (2017: 13) nilai nilai utama yang dikembangkan dalam etika pemerintahan yaitu:

1. Penghormatan terhadap hidup manusia dan HAM lainnya.

2. Kejujuran, baik terhadap diri sendiri maupun terhadap manusia lainnya (honesty).

3. Keadilan dan kepantasan merupakan sikap yang terutama harus diperlakukan terhadap orang lain .

4. Kekuatan moralitas, ketabahan, serta berani karena benar terhadap godaan (fortitude).

5. Kesederhanaan dan pengendalian diri (temperance)

6. Nilai-nilai agama dan sosial budaya termasuk nilai agama agar manusia bertindak secara profesional dan bekerja keras. 


\section{Good governance}

Konsep governance muncul lantaran adanya kinerja yang dianggap minim dalam pembangunan di negara-negara berkembang dan kerap dikaitkan dengan tata kelola pemerintahan yang buruk (poor governance) atau pemerintahan yang salah urus (mismanage governance) (Panda, 2008). Secara sederhana, good governance dimaknai sebagai sesuatu yang sifatnya transparan, representatif, akuntabel, dan merupakan proses pengambilan kebijakan yang partisipatif (Cheema \& Rondinelli, 2007).

UNDP dalam Aksa (2010:131) menyebutkan praktik good governance memiliki karakteristik sebagai berikut:

\section{Participation}

Maksudnya adalah bahwa semua warga negara memiliki suara dalam pengambilan keputusan atau dengan kata lain dilibatkan, baik secara langsung maupun melalui institusi-institusi yang mewakili kepentingannya.

2. Rule of law

Adanya aturan hukum dan penegakan hukum yang adil tanpa pandang bulu.

3. Transparancy

Adanya keterbukaan terhadap informasi. Sehingga publik dapat mengakses informasi yang dibutuhkan. Sehingga publik dapat memonitor kinerja pemerintah dan memahami setiap informasi yang diberikan.

4. Responsiveness

Lembaga dan proses yang ada harus melayani setiap stakeholders.

5. Consensus orientation

Good governance menjadi jembatan antara kepentingan-kepentingan yang berbeda untuk mendapatkan pilihan terbaik demi kepentingan yang lebih besar baik dalam hal kebijakan maupun prosedur.

6. Equity

Warga negara memiliki kesempatan yang sama untuk menjadi sejahtera dan diperlakukan sama dalam pelayanan publik. Artinya tidak ada diskriminasi.

7. Effectiveness and efficiency

Proses pelyanan publik harus tepat sasaran, yakni sesuai dengan apa yang telah digariskan dan menggunakan sumber daya yang tidak berlebihan.

8. Accountability

Pembuat kebijakan harus mampu mempertanggungjawabkan tindakannya kepada stakeholders. Akuntabilitas juga harus disesuaikan apakah untuk internal atau eksternal.

9. Strategic vision

Stakeholders harus memiliki cara pandang good governance dan pengembangan sumber daya manusia yang luas dan jauh ke depan sejalan dengan apa yang dibutuhkan untuk pembangunan.

Dalam perkembangannya, good governance dipopulerkan oleh lembaga-lembaga keuangan internasional (seperti Bank Dunia IMF, dan WTO), para ekonom, Amerika Serikat, dan para penganut neoliberal di seluruh dunia (Gerring \& Thacker, 2008).

\section{METODE}

Penelitian ini menggunakan pendekatan kualitatif. Dengan menggunakan pendekatan ini diharapkan peneliti dapat mengkaji dan menjelaskan mengenai persoalan etika ASN dalam kaitannya dengan upaya mewujudkan good governance. Penelitian ini merupakan penelitian deskriptif dimana peneliti hanya memotret atau menggambarkan konsep dan teori yang dikaji selama melakukan penelitian mengenai etika ASN dan good governance, khususnya terkait dengan fenomena banyaknya ASN yang yang sudah divonis incracht karena kasus korupsi tapi masih mendapatkan gaji dari negara karena status ASN-nya masih melekat.

Untuk mendukung pengungkapan fenomena-fenomena tersebut, peneliti menggunakan studi kepustakaan untuk mengumpulkan data-data yang relevan melalui sumber terpercaya, baik itu melalui buku, jurnal, artikel media masa, dan internet. Data dalam penelitian ini akan melalui empat tahapan analisis sebagaimana dikemukakan oleh Miles \& Huberman (1992) dalam Abas (2017: 80) yakni pengumpulan data, reduksi data, penyajian data, dan penarikan kesimpulan secara induktif. 


\section{HASIL DAN PEMBAHASAN}

Memberikan pelayanan publik yang berkualitas merupakan kewajiban atau tanggung jawab pemerintah terhadap masyarakat. Hal ini sebagaimana diatur dalam pasal 15 huruf (e) UU No.25 tahun 2009 tentang Pelayanan Publik. Untuk mewujudkan hal tersebut, etika menjadi salah satu pedoman bagi ASN dalam bertindak. Sehingga, tindakan-tindakan ASN tidak menyimpang dari norma-norma yang sudah digariskan.

Kasus korupsi yang dilakukan ASN jelas melanggar etika karena tidak sesuai dengan nilai moral yang berlaku di masyarakat, termasuk juga dengan nilai-nilai yang diatur dalam kode etik ASN. Karena apa yang dilakukan ASN terkait dengan korupsi bertentangan dengan nilai-nilai kejujuran dan ketidaktaatan pada peraturan perundangan yang berlaku.

Tidak adanya etika juga semakin dipertegas dengan adanya upaya peralawanan dari terpidana kasus

korupsi dengan menggugat pasal 87 ayat 4 huruf (b) ke Mahkamah Konstitusi. Jadi bukan mengundurkan diri yang dipilih, tapi mereka justru melawan upaya pemerintah untuk memberhentikan dengan tidak hormat.

Mengacu pada PP No. 42 tahun 2004 tentang Pembinaan Jiwa Korps dan Kode Etik Pegawai Negeri Sipil, maka dalam pelaksanaan tugas kedinasan dan kehidupan sehari-hari seorang PNS (ASN) harus berpedoman pada etika bernegara, etika berorganisasi, etika dalam bermasyarakat, etika terhadap diri sendiri, dan etika terhadap teman sejawat atau sesama PNS. Secara kasat mata, korupsi sebagaimana yang dilakukan oleh ASN berarti melanggar etika dalam bernegara dan etika terhadap diri sendiri.

Dalam pasal 8 mengenai etika bernegara, tepatnya pada huruf (d) disebutkan bahwa ASN harus menaati semua peraturan perundang-undangan yang berlaku dalam melaksanakan tugas. Kemudian pada huruf (f) disebutkan bahwa PNS harus tanggap, terbuka, jujur, dan akurat, serta tepat waktu dalam melaksanakan setiap kebijakan dan program Pemerintah. Selanjutnya, pasal 11 mengenai etika terhadap diri sendiri, pada huruf (a) disebutkan bahwa ASN harus jujur dan terbuka serta tidak memberikan informasi yang tidak benar. Pada poin huruf (c) dipertegas dengan perintah agar menghindari konflik kepentingan pribadi, kelompok, maupun golongan.

Korupsi yang dilakukan ASN jelas bertentangan dengan PP No. 42 tahun 2004, khususnya ihwal ketidak jujuran dan konflik kepentingan. Dengan kata lain, perilaku korup dari ASN telah melanggar etika yang seharusnya menjiwai dalam setiap tindakan mereka. Korupsi yang dilakukan ASN juga bertentangan dengan PP No. 53 tahun 2010 tentang Disiplin Pegawai Negeri Sipil. Di dalam pasal 3 PP tersebut, PNS memiliki kewajiban-kewajiban, diantaranya yaitu: PNS harus menaati segala ketentuan peraturan perundangundangan (ayat 4); PNS harus bekerja dengan jujur, tertib, cermat, dan bersemangat untuk kepentingan negara (ayat 9); PNS harus melaporkan dengan segera kepada atasannya apabila mengetahui ada hal yang dapat membahayakan atau merugikan negara atau Pemerintah terutama di bidang keamanan, keuangan, dan materiil (ayat 10);

Selanjutnya, di dalam pasal 4 PP No. 53 tahun 2010, PNS dilarang menyalahgunakan wewenang (ayat 1); Menjadi perantara untuk mendapatkan keuntungan pribadi dan/atau orang lain dengan menggunakan kewenangan orang lain (ayat 2); Melakukan kegiatan bersama dengan atasan, teman sejawat, bawahan, atau orang lain di dalam maupun di luar lingkungan kerjanya dengan tujuan untuk keuntungan pribadi, golongan, atau pihak lain, yang secara langsung atau tidak langsung merugikan negara (ayat 6); Memberi atau menyanggupi akan memberi sesuatu kepada siapapun baik secara langsung atau tidak langsung dan dengan dalih apapun untuk diangkat dalam jabatan (ayat 7); Menerima hadiah atau suatu pemberian apa saja dari siapapun juga yang berhubungan dengan jabatan dan/atau pekerjaannya (ayat 8);

Selain dalam Peraturan pemerintah, aturan mengenai etika ASN juga ada dalam pasal 3 UU No.5 tahun 2014 tentang Aparatur Sipil Negara. Pada pasal 3 huruf (b) disebutkan bahwa ASN sebagai profesi berlandaskan pada prinsip kode etik dan kode perilaku. Kemudian dalam pasal 4 huruf (g) nilai dasar ASN memelihara dan menjunjung tinggi standar etika yang luhur. Selanjutnya pada pasal 5 ayat 2 huruf (a) dikatakan bahwa kode etik dan kode perilaku itu ada agar ASN melaksanakan tugasnya dengan jujur, bertanggung jawab, dan berintegritas tinggi.

Namun yang menjadi fenomena menarik adalah bahwa korupsi yang dilakukan secara tegas dapat kita katakan sebagai bentuk pelanggaran etika, tetapi para ASN tersebut ternyata belum dipecat dan bahkan masih mendapatkan gaji dari negara. Berarti Pejabat Pembina kepegawaian selaku atasan mereka tidak menerapkan aturan yang berlaku. Dengan kata lain, pimpinan mereka telah melanggar etika. Jadi bukan hanya pelaku korupsinya yang melanggar etika, tapi Pejabat Pembina kepegawaian yang tidak segera memberhentikan mereka dengan tidak hormat juga melanggar etika. 
Permasalahan ini mulai sedikit demi sedikit terselesaikan setelah pejabat ditingkat pusat, khususnya Badan Kepegawaian Negara menyampaikan temuannya mengenai ribuan ASN yang sudah divonis bersalah terkait dengan kasus korupsi tapi masih menerima gaji dari negara. Akhirnya, dibuatlah SKB antara BKN, Kemenpan RB dan Kemendagri Nomor: 182/6597/SJ, Nomor: 15 Tahun 2018, dan Nomor:153/KEP/2018 Tentang Penegakan Hukum terhadap Pegawai Negeri Sipil yang Telah Dijatuhi Hukuman Berdasarkan Putusan Pengadilan yang Berkekuatan Hukum Tetap Karena MelakukanTindak Pidana Kejahatan Jabatan atau Tindak Pidana yang Ada Hubungannya dengan Jabatan.

Meskipun bergerak lambat, tapi data per 1 Agustus 2019 menunjukkan jumlah PTDH akhirnya mengalami kenaikan diangka 88 persen (BKN, 2018). Dari 98 ASN Tipikor di tingkat pusat, yang sudah diselesaikan sebanyak 84 orang, dan dari 2.259 ASN Tipikor ditingkat daerah sudah berhasil diselesaikan sebanyak 1.882 orang.

Terkait dengan upaya mewujudkan good governance, salah satu isu yang terkait dengan kajian ini yaitu mengenai rule of law. Kita tidak hanya bicara soal aturan hukum tapi juga penegakan hukum itu sendiri.

Dalam konteks ada tidaknya aturan hukum, jelas bahwa etika ASN telah diatur dalam peraturan perundangan, diantaranya yaitu: UU No. 5 tahun 2014 tentang Aparatur Sipil Negara, PP No. 53 tahun 2010 tentang Disiplin Pegawai Negeri Sipil, dan PP No. 42 tahun 2004 tentang Pembinaan Jiwa Korps dan Kode Etika Pegawai Negeri Sipil. Sayangnya, penegakan aturan tersebut yang tidak dilaksanakan dengan baik. Padahal ketentuan mengenai sanksi terkait dengan pelanggaran etika secara tegas telah diatur dalam peraturan perundangan tersebut.

Mengacu pada PP No. 53 tahun 2010, terdapat tiga jenis hukuman yang dapat diberikan kepada PNS yang melanggar disiplin (pasal 7 ayat 1), yaitu: hukuman disiplin ringan, hukuman disiplin sedang, dan hukuman disiplin berat. Hukuman disiplin ringan berupa (pasal 7 ayat 2): teguran lisan; teguran tertulis; pernyataan tidak puas secara tertulis. Hukuman disiplin sedang berupa (pasal 7 ayat 3): Penundaan kenaikan gaji berkala selama 1 (satu) tahun; penundaan kenaikan pangkat selama 1 (satu) tahun; dan penurunan pangkat setingkat lebih rendah selama 1 (satu) tahun. Hukuman berat berupa (pasal 7 ayat 4): Penurunan pangkat setingkat lebih rendah selama 3 (tiga) tahun; pemindahan dalam rangka penurunan jabatan setingkat lebih rendah; pembebasan dari jabatan; pemberhentian dengan hormat tidak atas permintaan sendiri sebagai PNS; dan pemberhentian tidak dengan hormat sebagai PNS.

Menurut UU No.5 tahun 2014 tentang ASN, pemecatan atau pemberhentian dapat dilakukan, baik itu dengan hormat maupun tidak dengan hormat. Pemberhentian Tidak Dengan Hormat antara lain dapat dilakukan terkait tindak pidana yang dilakukan karena kaitannya dengan jabatan (pasal 87 ayat 4). Aturna paling lemah ada pada PP No. 42 tahun 2004 tentang Pembinaan Jiwa Korps dan Kode Etika Pegawai Negeri Sipil. Dalam aturan tersebut, pelanggaran etika hanya diberikan sanksi moral yang sifatnya bisa terbuka dan tertutup. Kalau terbuka disampaikan dihdapan publik sedangkan tertutup disampaikan hanya kepada yang bersangkutan saja. Lemahnya penegakan aturan hukum ini menandakan bahwa kita masih jauh dari upaya mewujudkan good governance. Sehingga, keberadaan aturan yang harusnya mampu menjadi pedoman berperilaku agar sesuai dengan etika yang diharapkan menemui kegagalan. Hal ini berujung pada pelanggaran etika dan berdampak pada kualitas pelayanan publik yang tidak baik.

\section{KESIMPULAN DAN SARAN}

\section{Kesimpulan}

Apa yang terjadi dalam kasus dimana banyaknya ASN yang divonis bersalah dan putusannya sudah incracht memang jelas telah melakukan pelanggaran etika, khususnya aspek ketidakjujuran dan hanya mementingkan keuntungan diri dan kelompoknya saja dengan cara-cara ilegal. Ketersediannya aturan hukum sebagai wujud upaya menciptakan good governance dan sekaligus memformalkan etika ASN ternyata masih belum mampu membuat ASN tunduk pada etika yang harus ditaati dalam menjalankan tugasnya sebagai aparatur pemerintah.

Hal ini terkait dengan minimnya etika atasan atau pemimpin untuk menerapkan dan mengaplikasikan etika itu sendiri kepada bawahannya. Sehingga, tata kelola pemerintahan, yakni birokrasi sebagai perpanjangan tangan pemerintah hanya memberikan aturan bagi ASN untuk bertindak tapi tidak didukung dengan penegakan hukum itu sendiri yang sejatinya merupakan bagian penting dari good governance. Maka terkesan etika bagaimana berperilaku terkait dengan tugasnya sebagai pelayan publik justru terdegradasi dengan "etika" birokrat sebagai satu kesatuan korps yang harus saling "menjaga" dan "melindungi" dalam konotasi negatif. 


\section{Saran}

Ke depan, penegakan hukum menjadi sangat penting untuk dilakukan. Meskipun pada dasarnya bicara etika adalah bicara mengenai sesuatu yang muncul dari dalam diri dan harusnya sudah melekat. Tapi karena adanya kesadaran bahwa etika yang terkait dengan nurani tersebut bisa dilanggar maka negara pun akhirnya membuat instrumen hukum dimana ada konsekuensi atau sanksi bila dilanggar. Maka upaya penegakan hukum harus dilakukan. Bahkan bukan hanya bagi ASN yang memang melanggar tapi sanksi juga ahrus diberikan kepada atasan mereka yang tidak mau menerapkan aturan yang sudah ada. Karena pada prinsipnya mereka selaku atasan atau Pejabat Pembina Kepegawaian juga telah melanggar etika bila tidak menegakkan etika di lingkungannya.

\section{DAFTAR PUSTAKA}

Abas. 2016. Urgensi Etika dalam tata Kelola Pemerintahan (Governance). Journal of Public Sector Innovations, Vol 1 (2), p 83.

Aksa, Ahmad Husnan. 2010. Etika Administrasi Publik; Peranannya dalam Mewujudkan Good Governance. Jurnal Ilmiah Adminsitrasi Publik dan Pembangunan, Vol 1 (2), p 131.

Cheema, Shabbir G., \& Rondinelli A. Dennis. (Ed.). 2007. Decentralizing Governance (Emerging Concepts and Practice). Washington, D.C: Brooking Institution Press.

Dewi, M. P. (2017). The Problem of Basic Education Policy and Its Implementation in Indonesia. Advances in Economics, Business and Management Research (AEBMR), 43(Icas), 138-141.

Gerring, John., \& Thacker, Storm C. 2008. A Centripetal Theory of Democratic Governance. New York: Cambridge University Press.

Hamirul. 2017. Patologi Birokrasi Yang Dimanifestasikan Dalam Perilaku Birokrat Yang Bersifat disfungsional. Jurnal Ilmu Pemerintahan Otoritas, Vol 7 (1), p 16.

Ibrahim, Monalisa., \& Udin, Efanita. 2016. Etika Aparat Pemerintah Terhadap Kualitas Pelayanan Pembuatan Akta Jual Beli Tanah di Kecamatan Panca Rijang. Jurnal Akmen, Vol 13 (3), p 513-514.

Iskandar, Dadi Junaedi. 2016. Reaktualisasi Semangat Kepublikan Birokrasi di Era Reformasi. Jurnal Ilmu Administrasi, Vol 13 (1), p 141.

Kyohairwe, Stella B. 2015. Building ethics and integrity in the public sector in Uganda: A search for a superlative approach. The Ugandan Journal of Management and Public Policy Studies, Vol 9 (1), p 23.

Marsuki. 2019. Etika jabatan dan Aparatur Sipil Negara dalam Prinsip-Prinsip Good Governance. Meraja Journal, Vol 2 (2), p. 91-100.

Marwiyah, Siti. 2016. Pentingnya Etika Administrasi Publik Dalam Pemberantasan Korupsi Pada Perilaku Birokrasi Publik. Proceedings International Seminar. Jember: Universitas Muhammadiyah Jember.

Misra, Suresh. 2016. Strengthening of Ethical and Moral Values in Governance. New Delhi: Indian Institute of Public Administration.

Nigro, Felix A., \& Nigro, Llyod G. 2012. Administrasi Publik Modern (Yudi Santoso: Penerjemah). Yogyakarta: Palmall Yogyakarta.

Noer, Hamka Hendra. 2014. Ketidaknetralan BirokrasiI Indonesia (Studi Zaman Orde Baru Sampai Orde Reformasi). Jakarta: PT Elex Media Komputindo.

Nurdin, Ismail. 2017. Etika Pemerintahan: Norma, Konsep, dan Praktik Bagi Penyelenggara Pemerintahan. Yogyakarta: Lintang Rasi Aksara Books

Panda, Smitha Mishra. 2008. Engendering Governance Institutions: An Introduction. In: Panda, Smitha Mishra (ed), Engendering Governance Institutions (State, Market, and Civil Society). New Delhi: SAGE Publications India Pvt Ltd. p 15-39.

Sedarmayanti \& Nurliawati, Nita. 2012. Strategi Penguatan etika dan Integritas Birokrasi dalam Rangka Pencegahan Korupsi Guna Meningkatkan Kualitas Pelayanan. Jurnal Ilmu Administrasi, Vol 9 (3), p 337. 
Transparansi : Jurnal Ilmiah Ilmu Administrasi Vol 2 , No. 2, Desember 2019, pp. 179-187

186

Setiawan, Refly. 2016. Strategi Kedisiplinan Guru Dan Tenaga Administrasi Dalam Meningkatkan. eJKPP 
Jurnal Kebijakan dan Pelayanan Publik, Vol 2 (2), p 48.

Singo, A.T. 2018. Ethical Leadership in the Limpopo Provincial Public Service of South Africa: An Imperative for Good Governance. Disertasi. Limpopo: University of Venda.

Sukri, J., \& Idris, Muhammad., \& Burhanuddin. 2017. Penerapan Etika Administrasi Negara Dalam Pelayanan Kenaikan Pangkat di Kantor Badan Kepegawaian dan Diklat Daerah Kabupaten Gowa. Kolaborasi Jurnal Administrasi Publik, Vol 3 (1), p 115.

\section{Sumber lain:}

Siaran Pers BKN Nomor: 022/RILIS/BKN/IX/2018 dikeluarkan oleh Kepala Biro Humas BKN Mohammad Ridwan tanggal 13 September 2018. Dapat diakses di: http://www.bkn.go.id/wpcontent/uploads/2017/01/SIARAN-PERS-UPDATE-PNS-Tipikor-Inkracht-Aktif-Bekerja-diPemerintah-Daerah.pdf diakses oleh penulis Minggu, 9/1/2019 pukul 21.15.

Siaran Pers BKN Nomor: 061/RILIS/BKN/IV/2019 dikeluarkan oleh Kepala Biro Humas BKN Mohammad Ridwan tanggal 30 April 2019. Dapat diakses di: http://www.bkn.go.id/wpcontent/uploads/2017/01/SIARAN-PERS-30-APRIL-2019-PDF.pdf diakses oleh penulis Minggu, 9/1/20219 pukul 22.32 .

Siaran Pers Nomor: 073/RILIS/BKN/VIII/2019 dikeluarkan oleh Kepala Biro Humas BKN Mohammad Ridwan 